Einführung in die klassische Elektrodynamik Yon Dr. Johannes Fischer. Pp. viii +199. (Berlin : Julius Springer, 1936.) 13.80 gold marks.

THIs small volume on the classical electric theory contains a general, but not very novel, survey of the portions of the mathematical-physical theory which are still relevant in the broader technical applications of the subject. Starting with electrostatics, the author carries his readers carefully through all the important physical ideas underlying the static field theories of Maxwell and Faraday, including the theory of dielectrics. Following this, he introduces in a small chapter the field and energy relations of the magnetostatic field, basing himself on the analogy with the electrostatic field. The first section of the book closes with a brief survey of the kinematical problems of current flow in conducting media.

In the second section, the usual laws of electrodynamics are discussed in some detail, together with their application in current theory and its bearing on the problems of electro-technics. The treatment is based on the idea,s underlying Maxwell's equations, which are given in explicit form and used in the last chapters to develop the main ideas of the theory of the propagation of electromagnetic disturbances.

The author lays some stress on an endeavour to circumvent the difficulties in the assumptions underlying presentations of this subject via the rther theories, but one cannot but feel that he has been successful only to the extent to which he has avoided discussion of these difficulties. He gives, for example, the Kelvin-Larmor discussion of the polarization constituent of the total electric displacement, but says nothing whatever about the other constituent-the 'æthereal' one. His use also of the magnetic circuit to overcome some of the difficulties of the magnetic formulation really introduces more difficulties than it overcomes. He still fails to realize that the difficulties in the old-fashioned formulation of the magnetic relations all result from the use of the fundamentally faulty electric-magnetic analogy. It is also noticed that, like all Continental writers, the author still adheres to the form of the Maxwell stress deduced originally by Helmholtz by an argument which Larmor showed more than forty years ago to be physically unsound.

These are, however, perhaps small blemishes on a very brave and generally successful attempt to present in about 170 pages a reasoned account of a subject which most of us feel demands nearly four times this space.

G. H. I.

The Annual Register:

a Review of Public Events at Home and Abroad for the Year 1936. Edited by Dr. M. Epstein. Pp. $\mathrm{xii}+304+190$. (London, New York and Toronto : Longmans, Green and Co., Ltd., 1937.) 30s. net. THERE can be few events in the political or social history of Great Britain or the Empire that escape record in the pages of this widespanned annual. A dispassionate review of the year ranges over a field wide enough to include reduction in telephone charges and non-intervention in Spain. The Dominions and India follow, and then comes a long section treating of foreign history, preceded by several pages on the League of Nations. A few States have had a year so happily uneventful as to escape inclusion in the survey, but this is exceptional.

Part 2 of the book has the usual arrangement of a chronicle of events ; a retrospect of literature, art, science, finance and law. Science of the year is reviewed in epitome: much is mentioned in an extremely condensed form. Two among other general trends are noted: the growing disquiet among men of science at the frustration and prostitution of science for anti-social ends, and also the clear realization that advance in scientific thought can only come through intellectual freedom. Among the public documents published in full is the new Soviet constitution. An admirable index much facilitates reference.

\section{The Tropical Garden}

Its Design, Horticulture and Plant Materials. By Loraine E. Kuck and Richard C. Tongg. Pp. xi+ $378+16$ plates. (New York: The Macmillan Company, 1936.) 12s. $6 d$. net.

THE authors of this volume are writing primarily for gardeners in the Haiwaiian Islands, though, as the climate in this part of the Pacific is fairly typical of the moderate tropies everywhere, the information they give will be of use to a much wider public. They treat their subject from two angles, design and choice of suitable plants. In twenty-three chapters these two aspects are fully explored. The book is written in a popular and lively style, but is, nevertheless, scientifically accurate-as is to be expected from the list of helpers given in the preface.

The numerous photographs add to the value of the text, and the volume is well produced. A greater use might, however, have been made of italies for Latin names. The volume is a welcome addition to the rather meagre list of works on gardening in the tropics.

\section{Technical Electricity}

By H. T. Davidge and Robert W. Hutchinson. Fifth edition. Pp. $\mathrm{x}+520$. (London : University Tutorial Press, Ltd., 1936.) 12s. $6 d$.

WE can commend the fifth edition of this book highly. It is easy to understand, has been thoroughly brought up to date and will appeal to students, teachers and engineers. The answers are given to the problems set and many of them are completely worked out. Electrical engineers can refresh their memory about the fundamental facts of atomic dis. integration, thermionic valves and photo-electric cells. They will even find something instructive said about tariffs and the British Grid. We think, however, that the authors' résumé about the laws governing the sizes of fuses and the temperature rise in cylindrical conductors could have been improved. They have not laid sufficient stress on the important part played by thermal convection currents in this connexion. A better rule than the one given is that, within certain limits, the fusing current varies as the $1 \cdot 25$ th power of the radius of the wire. A proof is given by Russell (Proc. Phys. Soc., 22, 450). 